\title{
Separation and Identification of Phenolic Acid from Borago officinalis (F:Boraginaceae) Cultivated in Iraq
} Ashwaq T. Kareem*,1 and Maha N. Hamad*

*Department of Pharmacognosy and Medicinal Plants, College of Pharmacy, University of Baghdad, Baghdad, Iraq

\section{Abstract}

The plant Borago officinalis, which belongs to the Boraginaceae family and Celebrated as borage, is one of the useful medicinal plants cultivated in Iraq. It was used in old medicine in Iraq, Iran, Syria and Europe for management of various diseases. It is commonly used as a tonic, tranquilliser, management of cough,sore throat , pneumonia,urinary tract infection, rheumatoid arthrites

antioxidant, and anticancer. This project provides the first comprehensive research done in Iraq to study the phytochemicals and the methods of extraction and isolation of active constituents from Borago officinalis cultivated in Iraq. The plant was harvested in spring from AL-Rifai, Nassiriyah city/ IRAQ in February 2019. The aerial parts were washed carefully, dried under dark for two weeks, and milled in a mechanical grinder to a fine powder.The plant was extracted by cold extraction methods using $85 \%$ methanol solvent for three days then Fractionation with petrollium ether, chloroform, ethyl acetate and n-butanol(n.b) to separate the active constituents according to the change in polarities. The ethyle acetate fraction and n-butanol fraction were used for identification and isolation of phenolic compounds by TLC,PLC,HPLC and LC/mass. Results of the phytochemical screening exposed the presence of, phenols, tannins, fatty acid, in the plant extract. The phenolic acid(Sinapic acid , Rosmarinic acid , Caffeic acid) were separated and purified by PLC.The isolated compounds were subjected to several chemical, chromatographic and spectral analytical techniques for their identification such as TLC, HPLC,UV andLC/mass.

Keywords: Sinapic acid, Rosmarinic acid, Caffeic acid, HPLC, Lc/Mass.

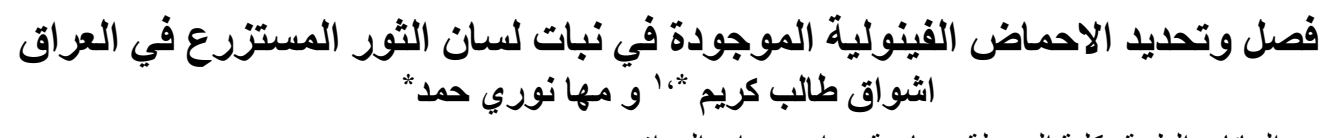

$$
\text { *فرع العقاقير و النباتات الطبية ،كلية الصيدلة ، جامعة بغداد ، بغداد ،العر اق. }
$$

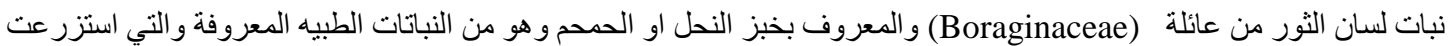

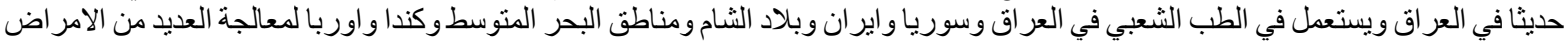

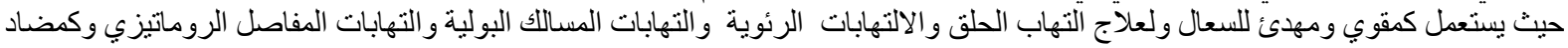

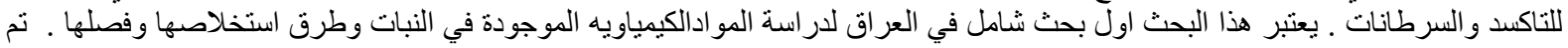

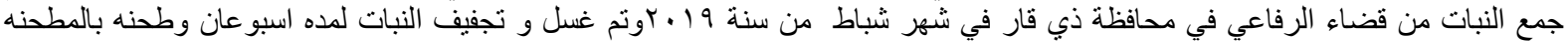

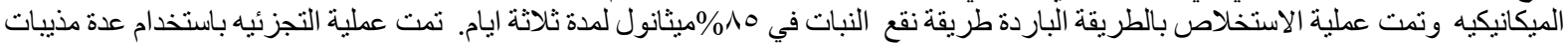

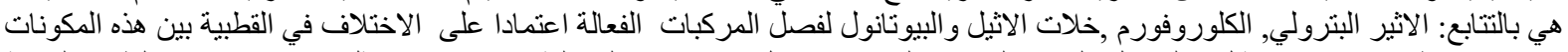

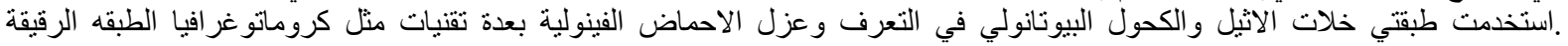

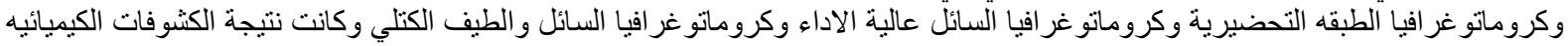

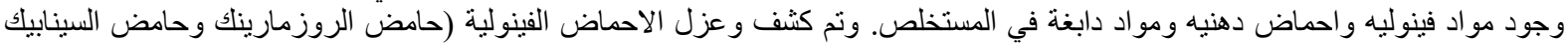

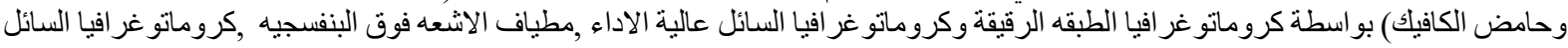
و الطيف الكتلي.

الكلمات المفتاحية: حامض الروزماريك ، حامض السنابيك,حامض الكافيك،كروماتوغرافيا السائل عالية الاداء، كروماتوغرافياالسائل والطيف الكتلي.

\section{Introduction}

Borage (Borago officinalis L.) is an annual plant belonging to the family. Boraginaceae. It originates from Western regions of Mediterranean area and grows nearly in whole America, Europe, Canada and Iran ${ }^{(1,2)}$. The plant grows during November to January and reaches a height of 70 to $100 \mathrm{~cm}^{(3,4)}$ Its stem is shielded with hairs that secrete a strong smell nearly the aroma of fresh cucumbers while on the tops of the shoots there are the starshaped inflorescences which initially are pink, later turn blue, seldom white ${ }^{(5,6)}$.
Aerial parts have been used in old medicine in Iraq as atonic, tranquillizer, management of cough, pneumonia, sore throat, swelling and inflammatory diseases. The leaves and flower possess biological activities for cancer and heart diseases prevention (7) and have antibiotic properties (8), condense cardiovascular diseases ${ }^{(9)}$ and provide benefits for improving health due to their various biological events ${ }^{(10)}$.

${ }^{1}$ corresponding author E-mail: ashotalib@gmail.com

Received: 6 / 2 /2020

Accepted: 20/ 5/2020

Iraqi Journal of Pharmaceutical Science 
Results reported by previous studies shown the presence of phenolics acid, flavonoids (Quercetin, Myricetin, Luteolin and Rutin) and isoflavonoid besides, the dominant individual fatty acids of methanolic extract as Oleic acid which is an unsaturated fatty acid (omega-9), linoleic fatty acids (omega-6) and Hexadecanoic acid. The methanolic extract was more biologically active than ethanolic extract ${ }^{(11)}$.

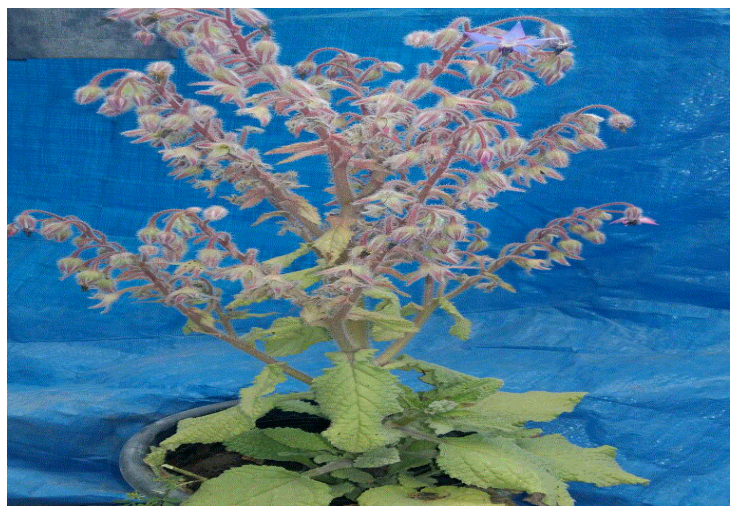

Figure 1. Borago officinal plant cultivated in $\operatorname{Iraq}^{(12)}$

\section{Material and Method \\ Plant collection}

Borago officinalis plant was harvested from AL-Rifai, Nassiriyah city/ IRAQ in February 2019. The aerial plant was dried in the shadow for two weeks and powdered. The plant was identified and authenticated by Prof. Dr Israa Mohammed Department of Biology /College of Sciences/ University of Baghdad.

\section{Extraction and fractionation of the different active constituent}

Two hundred and fifty grams of the powdered plant material was soaked in $1500 \mathrm{ml}$, with $85 \%$ methanol and shaking, at room of temperature. After three days, the methanol soluble materials was filtered off. The filtrate was evaporated until dryness under vacuum using a rotatory evaporator. A dark greenish residue was obtained. Then suspended in $500 \mathrm{ml}$ water and partitioned successively with petroleum ether (B.p. $30-60{ }^{\circ} \mathrm{C}$ ), chloroform, ethyl acetate, and n-butanol $(3 \times 500 \mathrm{ml})$ for each fraction the first three fractions dried over sodium sulfate anhydrous, filtered, and evaporated to dryness ${ }^{(13,14)}$. The scheme of fractionation is shown in (Figure 2).

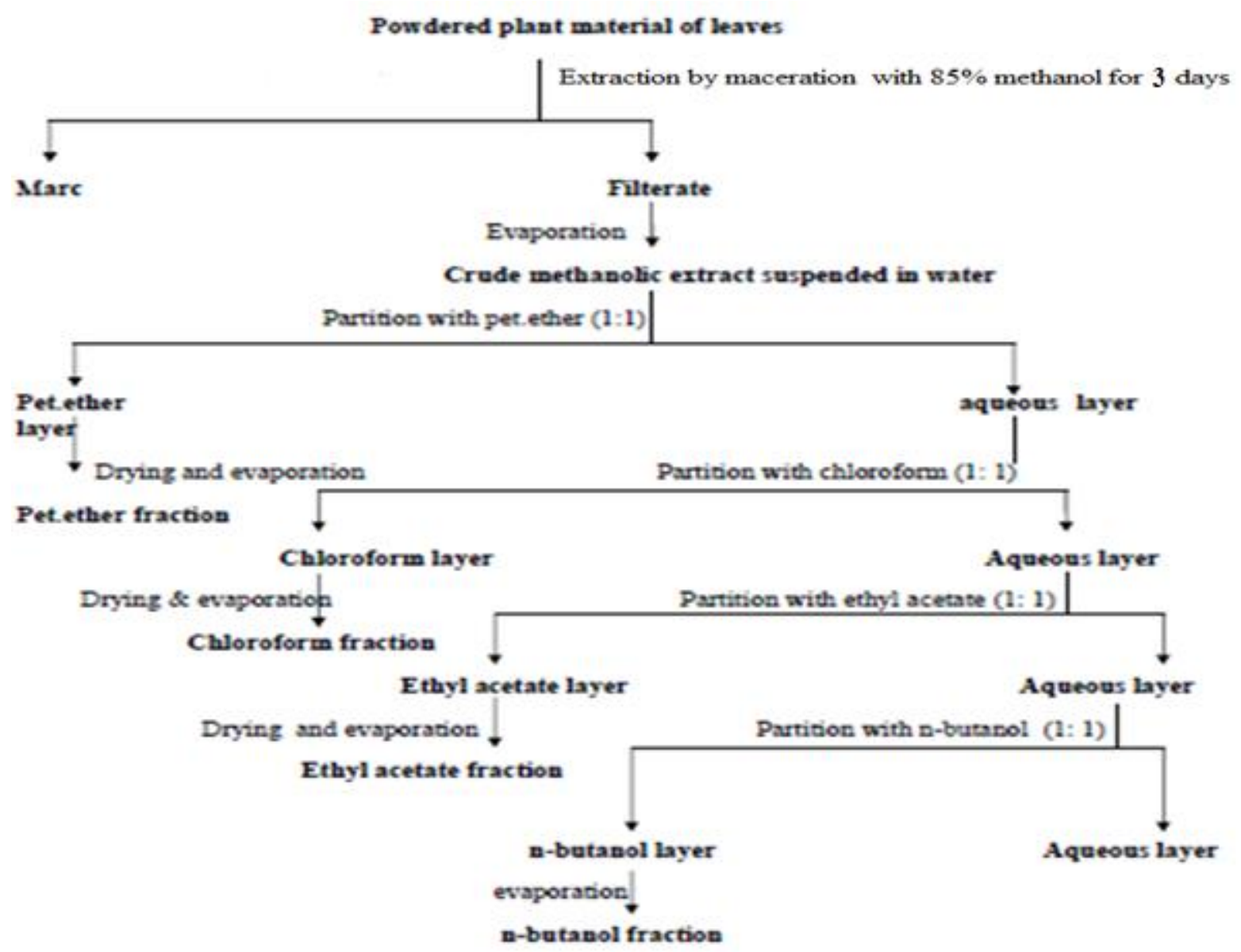

Figure 2. Schematic diagram for fractionations aerial part crude extracts of Borago officinalis ${ }^{(14)}$ 
Identification of phenolic compounds in Borago officinalis plant extract

1. Preliminary phytochemical showing of the phenolic compound using a methanolic extract from the plant using a $\mathrm{NaOH}$ test, lead acetate, and ferric chloride test ${ }^{(15,16)}$.

2. Isolation and purification of phenolic compounds from the fractions ethyl acetate and n.butanole by preparative layer chromatography. Isolation of phenols was done by using preparative TLC; 2 gram of each fraction dissolve in 10 mlof methanole and applied to the number of PLC plates as a semi concentrated solution in streak using a capillary tube on each plate, then the plate placed inside glass tank which contained the S1 solvent system. The band had been scrapped off, eluted with methanol and then filtered, the filtrate evaporated to dryness, in a vacuum as shown in Figure 3 and 4.

3. Thin-layer chromatography. In this qualitative identification, a ready-made aluminium plates of silica gel of 245 with developing solvent systems were used for detection the plant phenols in fractions ethyl acetate and n.butanole with standards, as listed in Table (1).

Table 1. Developing solvent systems using in the separation of phenols in Borago Officinalis.

\begin{tabular}{||c|l|c||}
\hline No. & \multicolumn{1}{|c|}{ Composition } & References \\
\hline S1 & $\begin{array}{l}\text { chloroform: ethyl acetate : } \\
\text { methanol :formic acid } \\
(70: 14: 14: 10)\end{array}$ & $(17)$ \\
\hline S2 & $\begin{array}{l}\text { Dichloromethan:acetonitrile } \\
\text { :formic acid(9.5:0.5:0.1) }\end{array}$ & $\begin{array}{l}\text { (17) } \\
\text { 10). }\end{array}$ \\
\hline S3 & \begin{tabular}{l} 
Chloroform:methanol $(90:$ \\
\hline
\end{tabular} \\
\hline
\end{tabular}

4. Qualitative estimate of ethyl acetate and n.butanole fractions by high-performance liquid chromatography (HPLC) the expected phenols in fractions were separated by HPLC method and detected in comparison with standard compounds . The mobile phase consisted $1 \%$ aq. Acetic acid solution (A) and acetonitrile (B) solvents, the flow rate was adjusted to $0.7 \mathrm{ml} / \mathrm{min}$, the column was thermostatically controlled at $280 \mathrm{C}$, and the injection volume was kept at $20 \mu \mathrm{l}$. Gradient elution was accomplished by varying the proportion of B to A solvents. The gradient elution was changed from $10 \%$ to $40 \% \mathrm{~B}$ in a linear fashion for $28 \mathrm{~min}$, from (40 to 60) $\% \mathrm{~B}$ in 39 min, after that from ( 60 to 90 ) \% B solution in $50 \mathrm{~min}$. The mobile phase mixture back to the initial state of solvents (B: A: 10: 90) in $55 \mathrm{~min}$ and permitted to run for another ten min.

5. LC-MS Analytical was done using the Agilent System joined to an Applied Biosystems API 2000 mass spectrometry.Mobile phase solvents acetonitrile and wate A column of $0.19 \mathrm{~mm}$ external diameter (75 $\mu \mathrm{m}$ I.D.) and $200 \mathrm{~mm}$ length was packed with Thermo Scientific Hypersil Gold C18 with $5 \mu \mathrm{m}$ particle size. Samples were run under the following conditions : $\mathrm{m} / \mathrm{z}$ range was 250 to $1000,200 \mathrm{~K}$ resolution, top 5 configurations with one MS scan and five MS/MS scans, and dynamic exclusion set to 1 with a limit of 90 seconds. A 2.5 hour LCMS separation was used for all blank and standard samples.

\section{Results and Discussion}

Borago officinalis plant active constituents

In this study, cold extraction method was done by $85 \%$ absolute methanol to extract the active constituent depend on the nature of these active constituents.Each $250 \mathrm{~g}$ of plant extract yielded $32 \mathrm{~g}$ residue

Preliminary qualitative phytochemical analysis

The results of the phytochemical analysis of polyphenol in methanolic crude extract given in ( Table 2).

Table 2. Results of the phytochemical analysis of polyphenol in the methanolic crude extract

\begin{tabular}{|c|c|c|c||}
\hline $\begin{array}{c}\text { Active } \\
\text { group }\end{array}$ & Test & Reaction & Result \\
\hline $\begin{array}{c}\text { Poly } \\
\text { phenol }\end{array}$ & $\begin{array}{c}\text { Lead } \\
\text { acetate } \\
\text { test }\end{array}$ & $\begin{array}{c}\text { White } \\
\text { ppt }\end{array}$ & positive \\
\hline Polyphenol & $\begin{array}{c}\text { Ferric } \\
\text { chloride } \\
\text { test }\end{array}$ & $\begin{array}{c}\text { Dark } \\
\text { green } \\
\text { colour }\end{array}$ & positive \\
\hline $\begin{array}{c}\text { Poly } \\
\text { phenol }\end{array}$ & $\begin{array}{c}\text { NaOH } \\
\text { test }\end{array}$ & $\begin{array}{c}\text { Yellow } \\
\text { colour } \\
\text { after } \\
\text { addition } \\
\text { NaOH } \\
\text { solution }\end{array}$ & positive \\
\hline
\end{tabular}

The isolation of phenols were done by using preparative TLC, in jar contained the S1 solvent system. As in Figure 3 and 4.

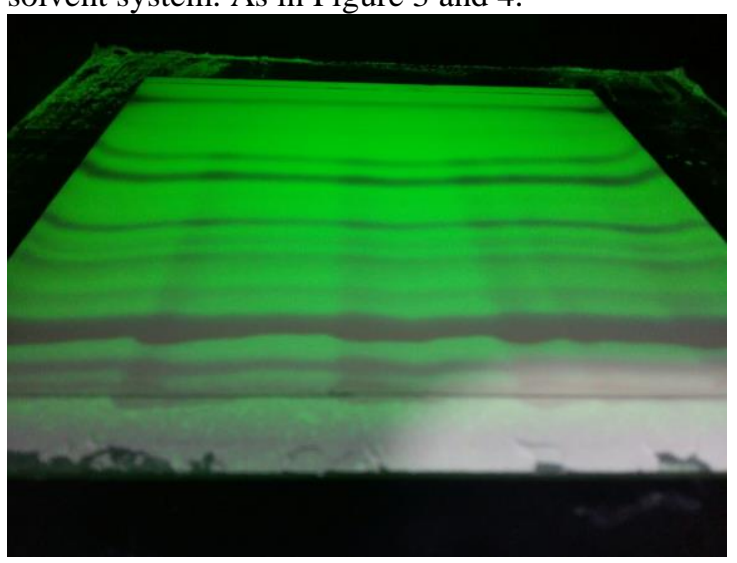

Figure 3. Preparative thin layer chromatography plate for ethyl acetate fraction on silica gel GF254 developed in the S1 system, detection by UV light at $254 \mathrm{~nm}$. 


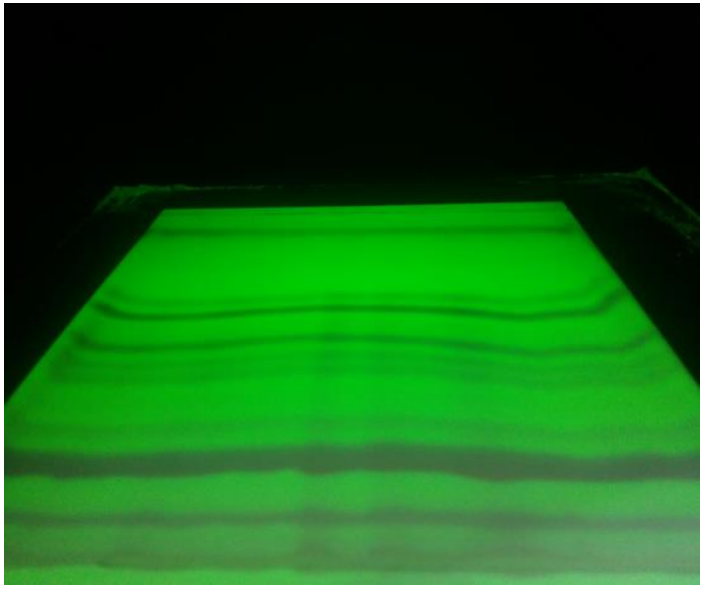

Figure4. Preparative thin-layer chromatography plate for n.b fraction on silica gel GF254 developed in the $\mathrm{S} 1$ system, detection by UV light at 366nm.

Table 3. TLC profile of isolated compound (cpd) number 1 compared with standard rosmarinic acid using the mobile phase solvents ( $S 1, \mathrm{~S} 2$, S3).

\begin{tabular}{||c|c|c|}
\hline $\begin{array}{c}\text { Solvent } \\
\text { system }\end{array}$ & $\begin{array}{c}\text { Rf of } \\
\text { standard } \\
\text { Rosmarinic } \\
\text { acid }\end{array}$ & $\begin{array}{c}\text { Rf of isolated } \\
\text { Phenolic acid } \\
\text { number 1 }\end{array}$ \\
\hline S1 & 0.247 & 0.246 \\
\hline S2 & 0.13 & 0.13 \\
\hline S3 & 0.2 & 0.2 \\
\hline
\end{tabular}

Table 4. TLC profile of isolated compound number 2 compared with sinapic acid standard using the mobile phase solvents ( S1, S2, S3)

\begin{tabular}{|c|c|c||}
\hline $\begin{array}{c}\text { Solvent } \\
\text { system }\end{array}$ & $\begin{array}{c}\text { Rf of standard } \\
\text { Sinapic } \\
\text { acid }\end{array}$ & $\begin{array}{c}\text { Rf of isolated } \\
\text { Phenolic acid } \\
\text { number } 2\end{array}$ \\
\hline S1 & 0.71 & 0.71 \\
\hline S2 & 0.47 & 0.47 \\
\hline S3 & 0.5 & 0.51 \\
\hline
\end{tabular}

Table 5. TLC profile of isolated compound number 3 compared with caffeic acid standard using the mobile phase solvents ( S1, S2, S3).

\begin{tabular}{||c|c|c||}
\hline $\begin{array}{c}\text { Solvent } \\
\text { system }\end{array}$ & $\begin{array}{c}\text { Rf of standard } \\
\text { caffeic acid }\end{array}$ & $\begin{array}{c}\text { Rf of isolated } \\
\text { Phenolic acid } \\
\text { number 3 }\end{array}$ \\
\hline S1 & 0.517 & 0.517 \\
\hline S2 & 0.182 & 0.182 \\
\hline S3 & 0.294 & 0.293 \\
\hline
\end{tabular}

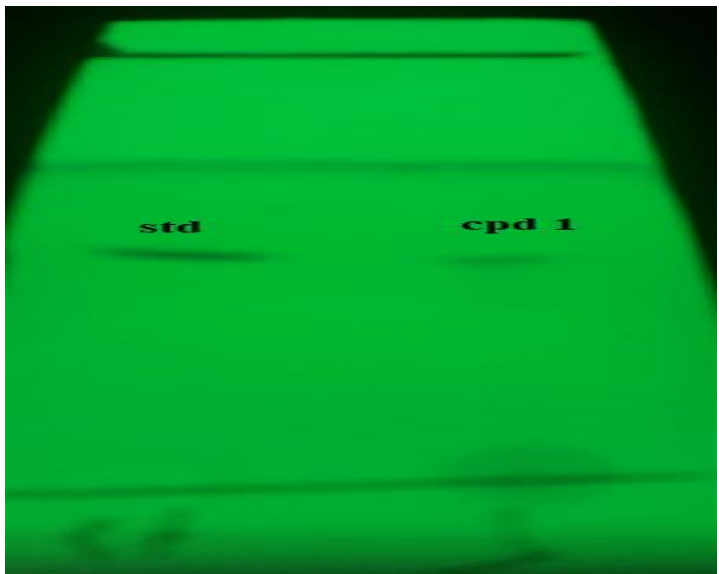

A

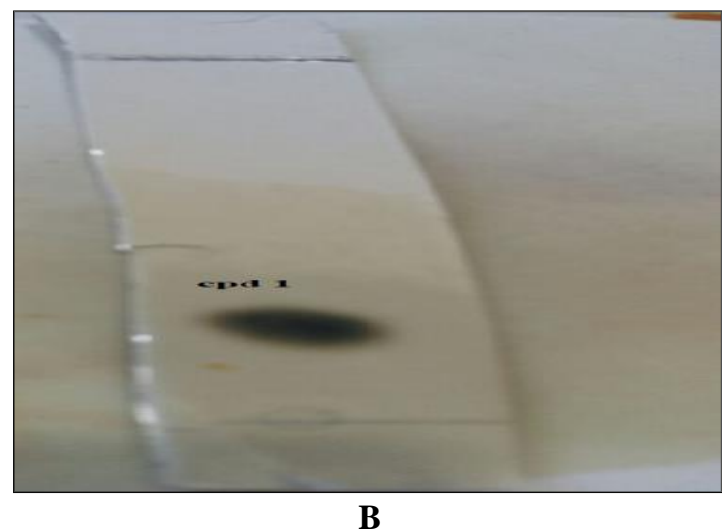

Figure 5. TLC chromatography (A) for separated compound number (1) from ethyl acetate fraction and Rosmarinic acid STD using silica gel Gf254 as adsorbant and S1 as mobile phase and (B) separated compound after detected by spraying with five \%ferric chlorides.

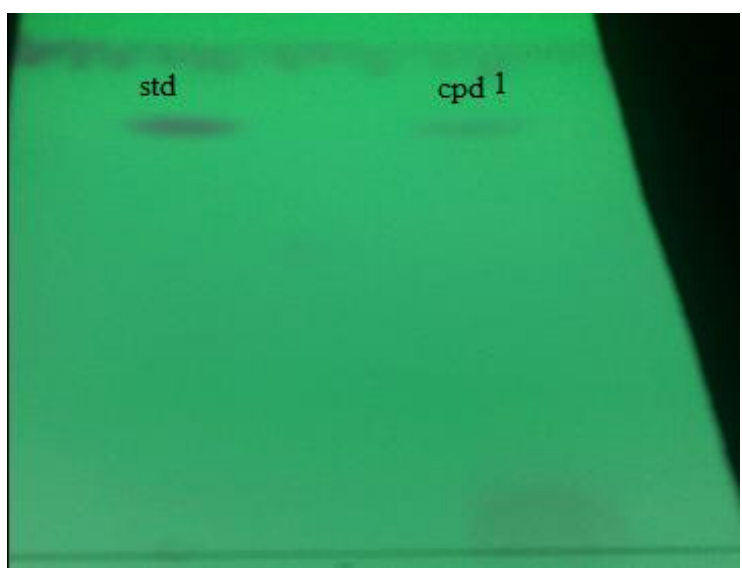

Figure 6. TLC chromatography for separated compound number (1) from ethyl acetate fraction and R.A standard using silica gel Gf254 as adsorbant and mobile phase $\mathbf{S 2}$. 


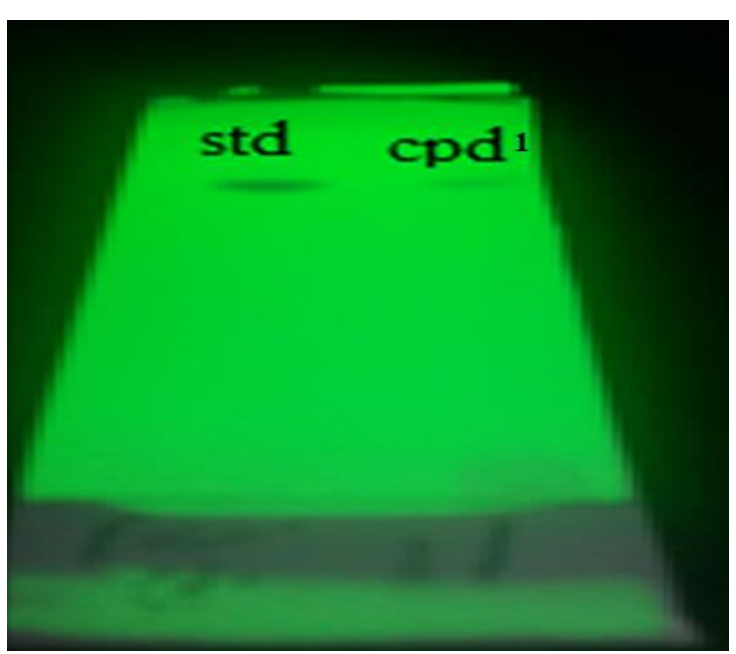

Figure 7. TLC chromatography for isolated compound number (1) from ethyl acetate fraction and Rosmarinic acid standard using silica gel Gf254 as adsorbant and mobile phase S3.

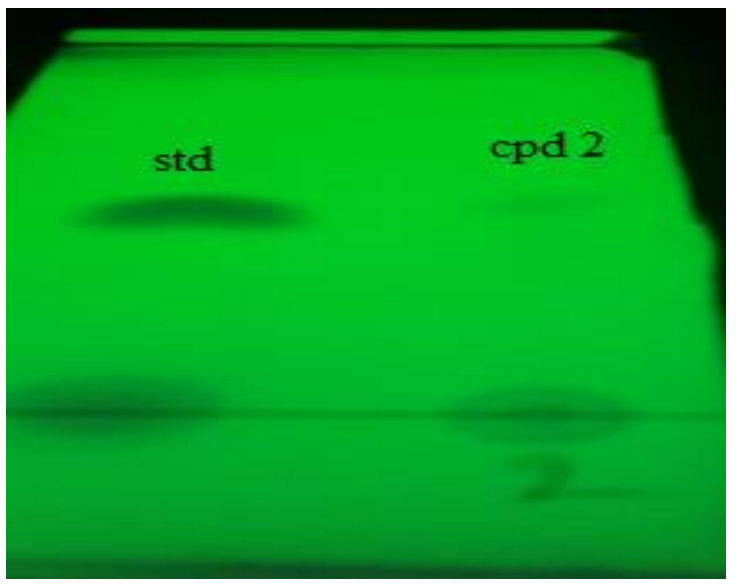

A

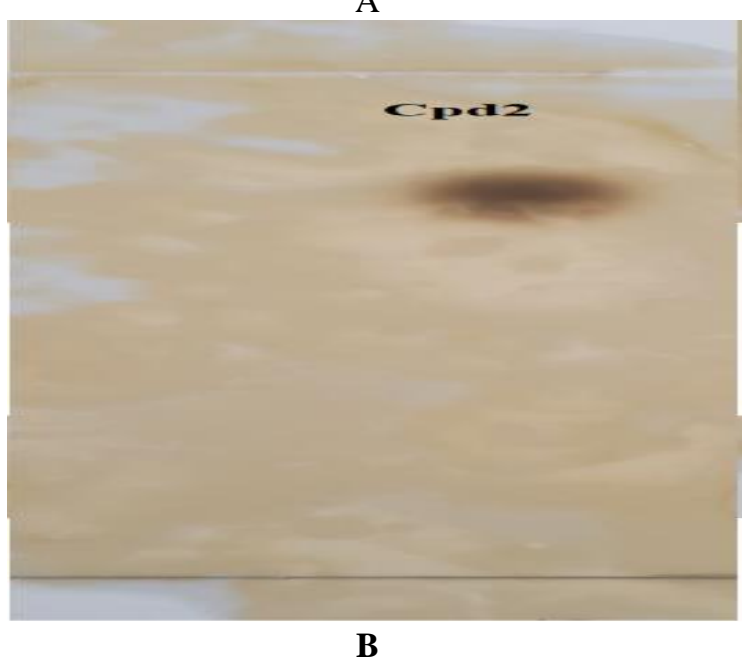

Figure 8. TLC chromatography(A) for isolated compound number (2) from ethyl acetate fraction and Sinapic acid standard using silica gel Gf254 as adsorbant and mobile phase S1 (B) separated compound after detected by spraying with five \%ferric chlorides.

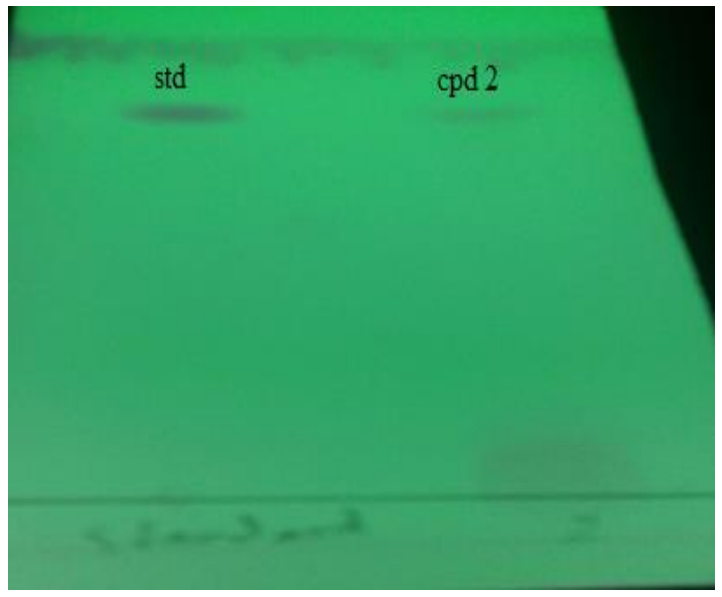

Figure 9. TLC chromatography for isolated compound number (2) from ethyl acetate fraction and standard S.A using silica gel Gf254 as adsorbant and mobile phase $\mathbf{S 2}$.

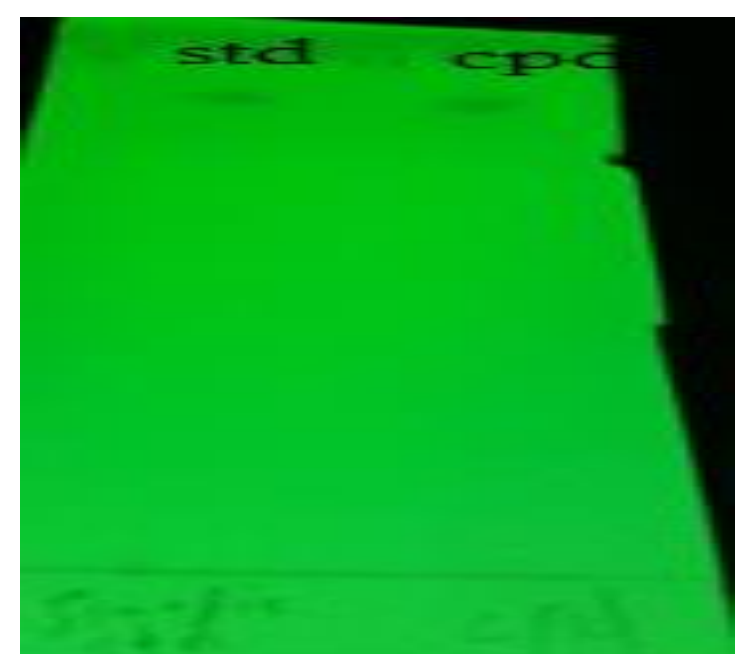

Figure 10. TLC chromatography for isolated compound number (2) from ethyl acetate fraction and S.A standard using silica gel Gf254 as adsorbant and $\mathrm{S3}$ as mobile phase. 


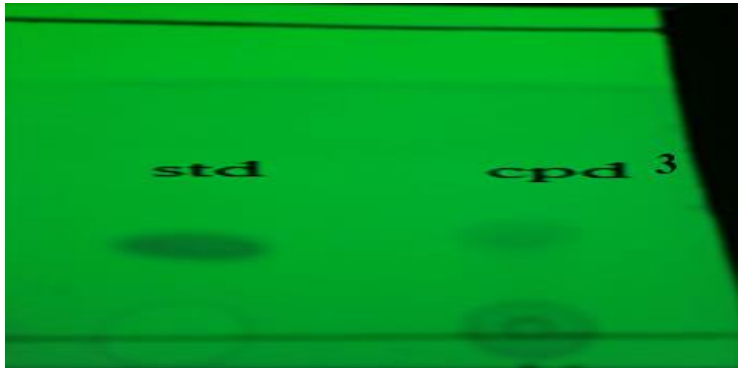

A

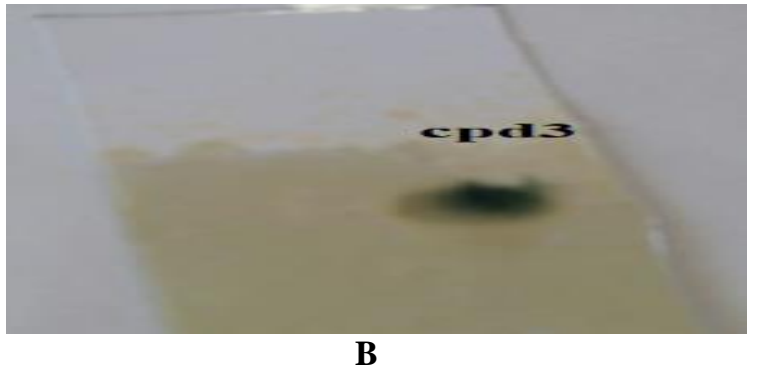

Figure 11. TLC chromatography (A) for separated compound number (3) from ethyl acetate fraction and Caffeic acid STD using silica gel Gf254 as adsorbant and $\mathrm{S1}$ as mobile phase and $(B)$ separated compound number 3 after detected by spraying with five \%ferric chloride.

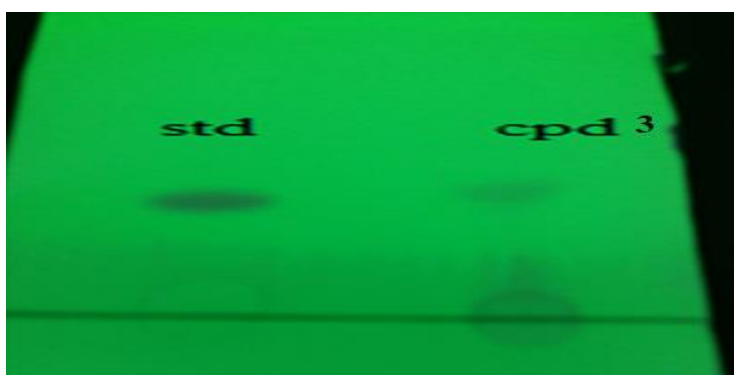

Figure 12. TLC chromatography for isolated compound number (3) from ethyl acetate fraction and caffeic acid standard using silica gel Gf254 as adsorbant and mobile phase $\mathbf{S 2}$.

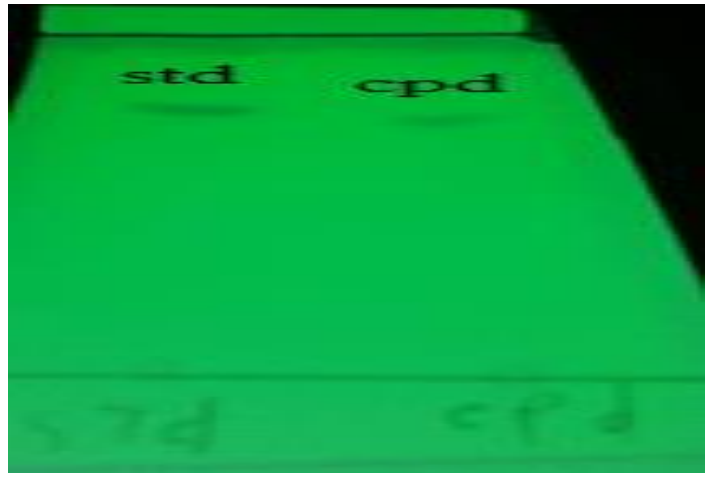

Figure 13. TLC chromatography for isolated compound number (3) from ethyl acetate fraction and caffeic acid standard using silica gel Gf254 as adsorbant and S3 as mobile phase

\section{HPLC analysis} method.

The result gained from HPLC analysis

1. The retention time of Rosmarinic acid standard match with a retention time of isolated compound number 1 and UV spectrum of separated compound number 1 match with UVs spectrum of Rosmarinic acid standard as in Figure 14and 15 and Table 6.

2. The retention time of the isolated compound number 2 match with a retention time of Sinapic standard and UV spectrum of the separated compound number 2 match with standard Sinapic acid as in Figure 16 and 17 and Table 6.

3 . The retention time of the isolated compound number 3 match with a retention time of Caffeic acid standard and UV spectrum of the separated compound number 3 match with Caffeic acid standard as in Figure 18 and 19 and Table 6.

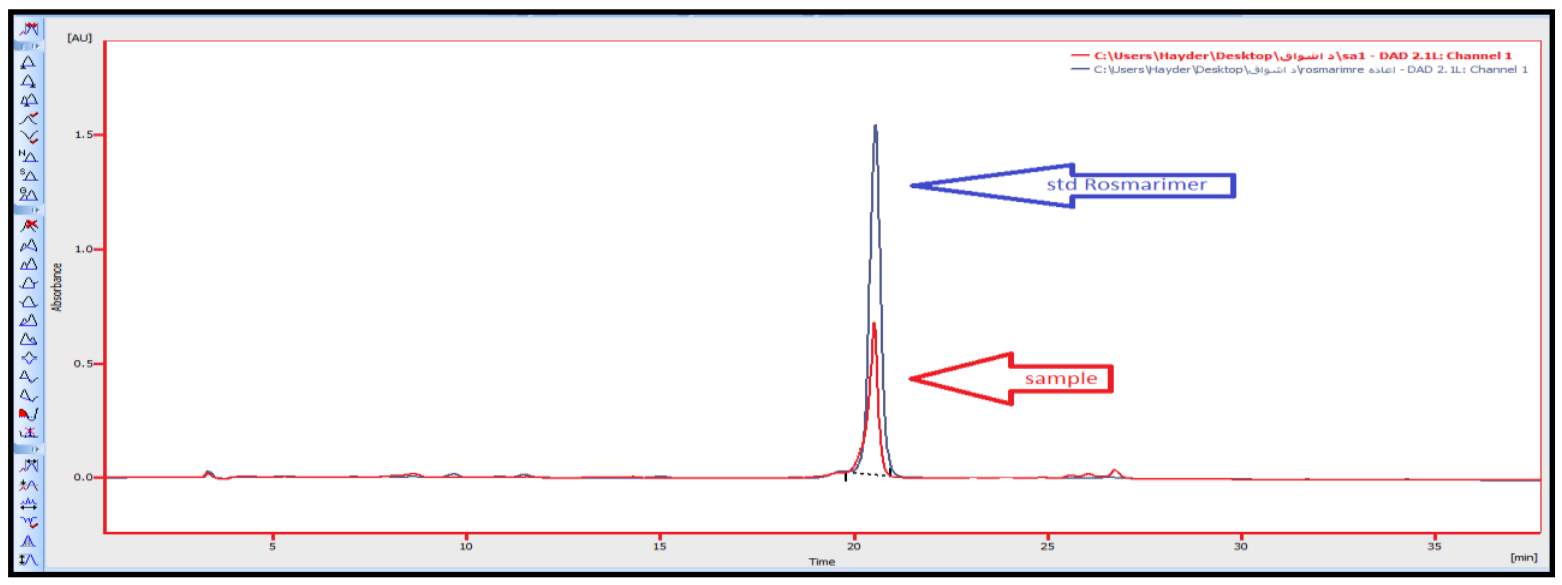

Figure 14. HPLC chromatogram of isolated compound number 1 and Rosmarinic acid standard. 


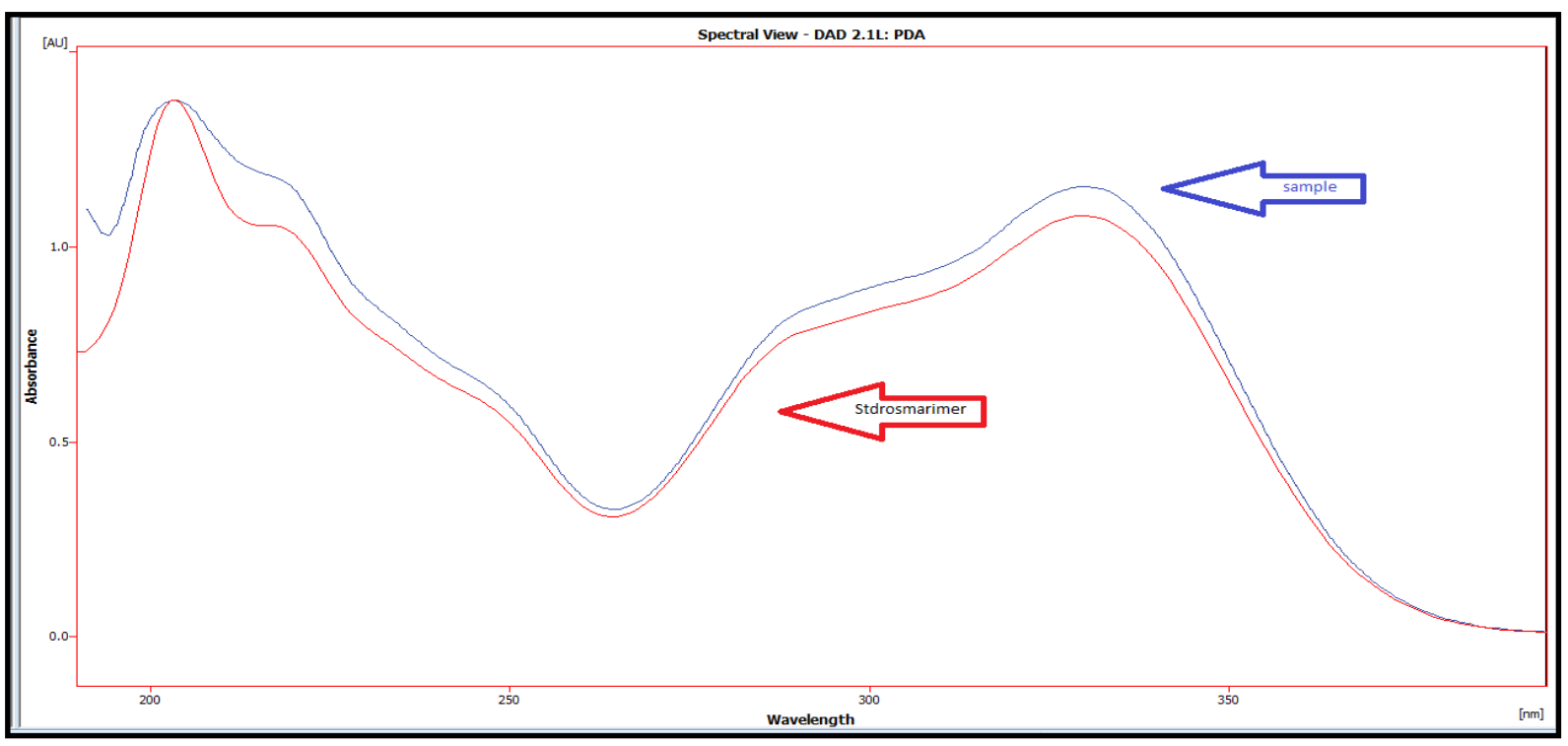

Figure 15. The UV spectrum of isolated compound number1 and Rosmarinic acid standard.

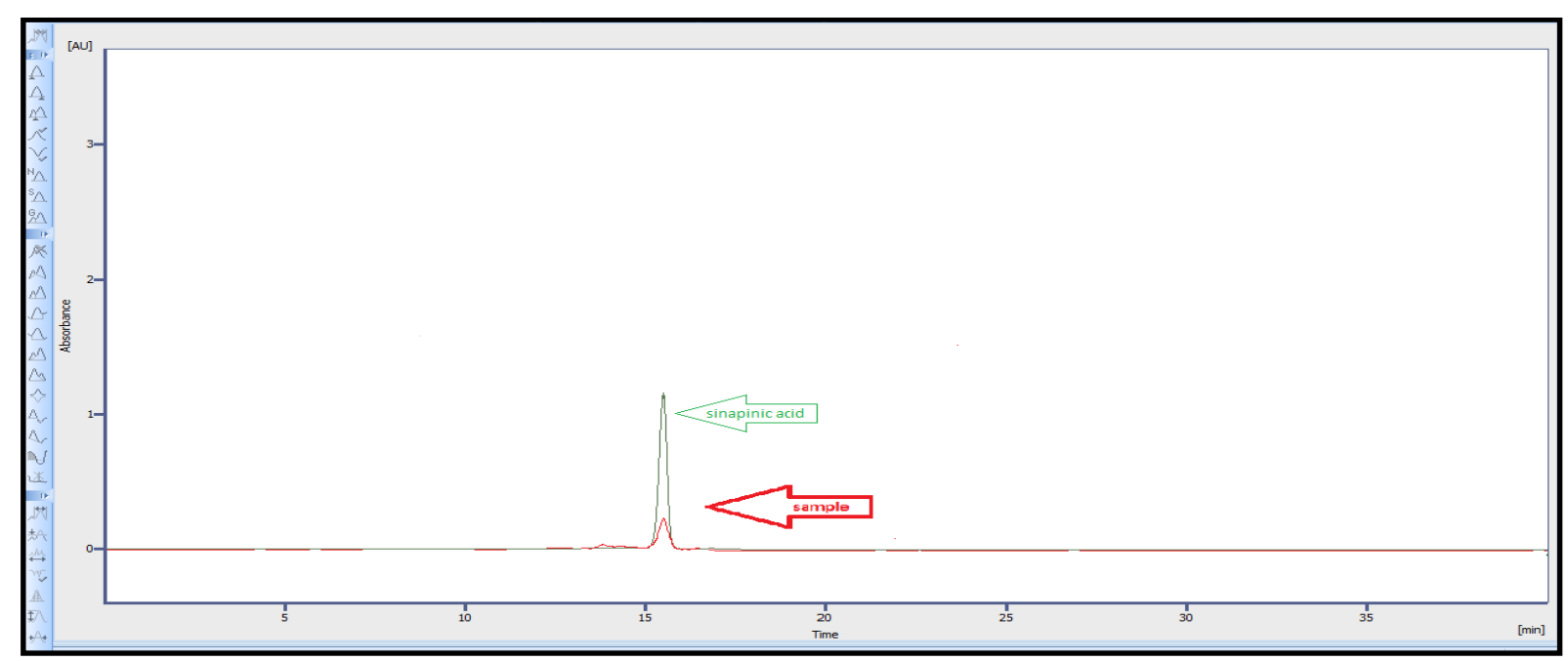

Figure 16. HPLC chromatogram of the isolated compound number 2 and Sinapic acid standard.

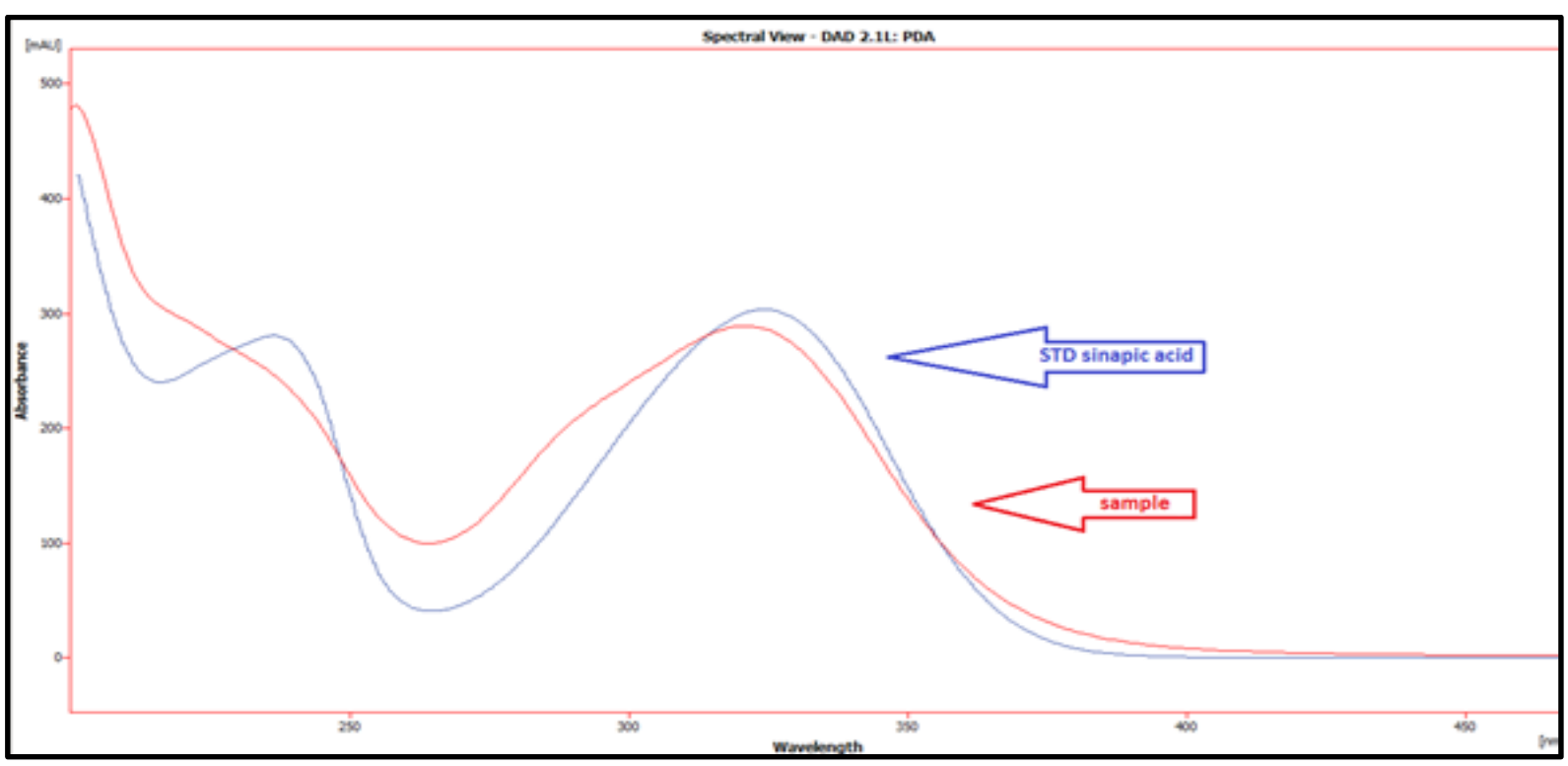

Figure 17. The UV spectrum of isolated compound number 2 and Sinapic acid standard. 


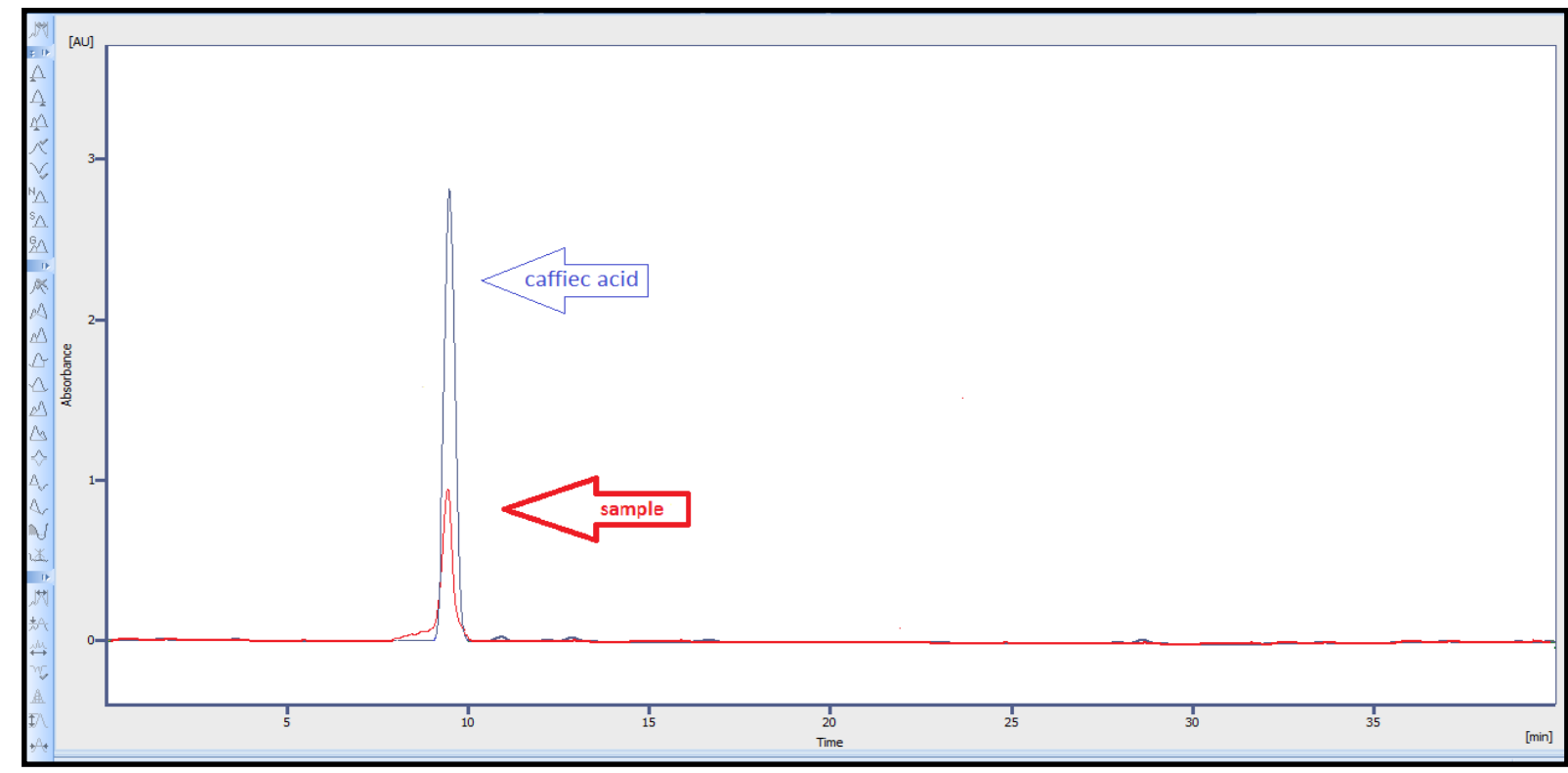

Figure 18. HPLC chromatogram of Caffeic acid standard and isolated compound number 3.

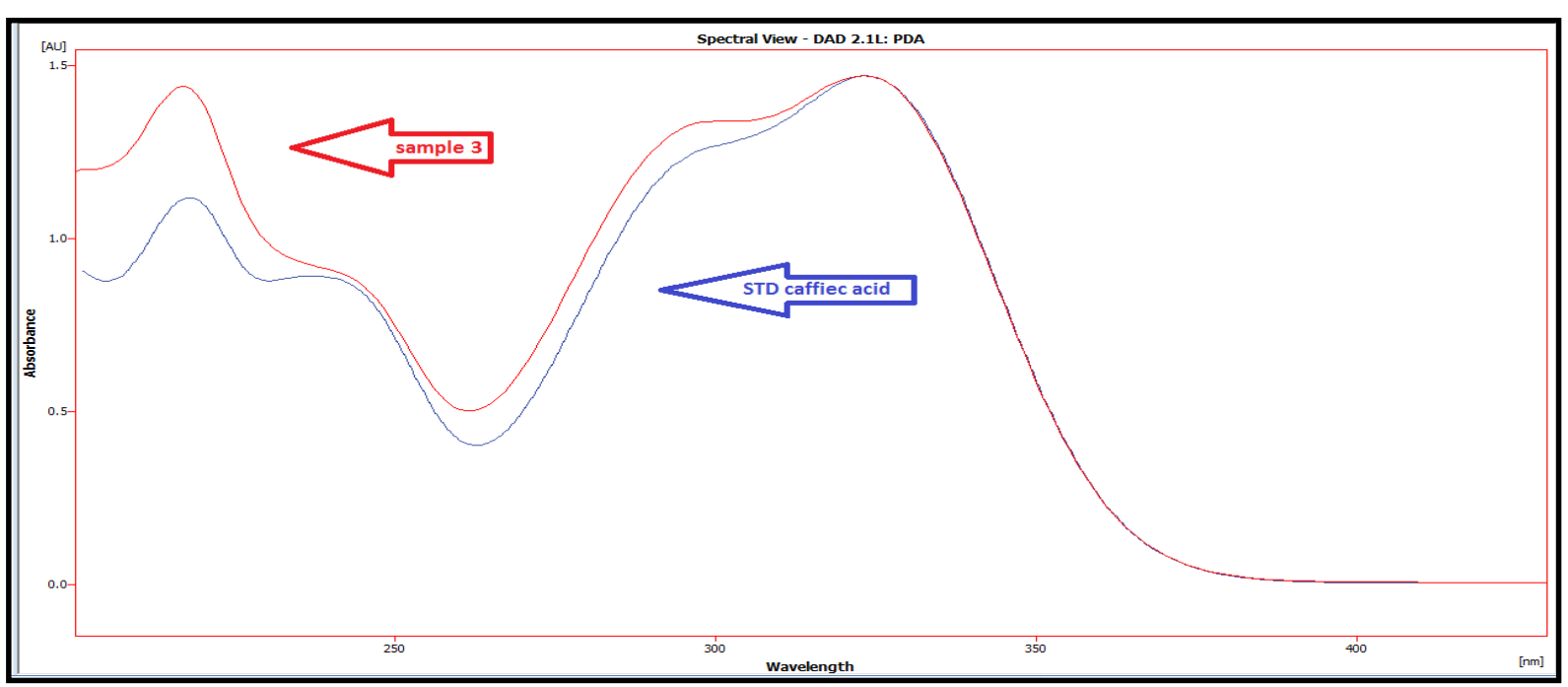

Figure 19. UV spectrum of isolated compound number 3 and caffeic acid standard.

Table 6.Retention times in minutes for standards (rosmarinic acid, sinapic acid, caffeic acid)and isolated cpd 1,2,3.

\begin{tabular}{||l|l||}
\hline Retention time of Rosmarinicacid standard. & Retention time for isolated cpd number 1. \\
\hline 20 & 20 \\
\hline Retention time of Sinapic acid standard. & Retention time for isolated cpd number 2. \\
\hline 15 & 15 \\
\hline Retentiontime of Caffeic acid standard. & Retention time for isolated cpdnumber3. \\
\hline 10 & 10 \\
\hline
\end{tabular}

\section{LC/mass}

The result gained from $\mathrm{LC} / \mathrm{mass}$.

1. LC/mass chromatogram as shown in( Figure 20) the isolated compound number 1 is Rosmarinic acid with molecular weight $360.31 \mathrm{Gram} / \mathrm{mol}$ as shown in Figure (21).

2. LC/mass chromatogram as shown in( Figure 22) the isolated compound number 2 is Sinapic acid with molecular weight $224.21 \mathrm{Gram} / \mathrm{mol}$ as shown in Figure(23).

3. LC/mass chromatogram as shown in( Figure 24) the isolated compound number 3 is caffeic acid with molecular weight $180.16 \mathrm{Gram} / \mathrm{mol}$ as shown in Figure (25). 


\section{Qualitative Analysis Report}

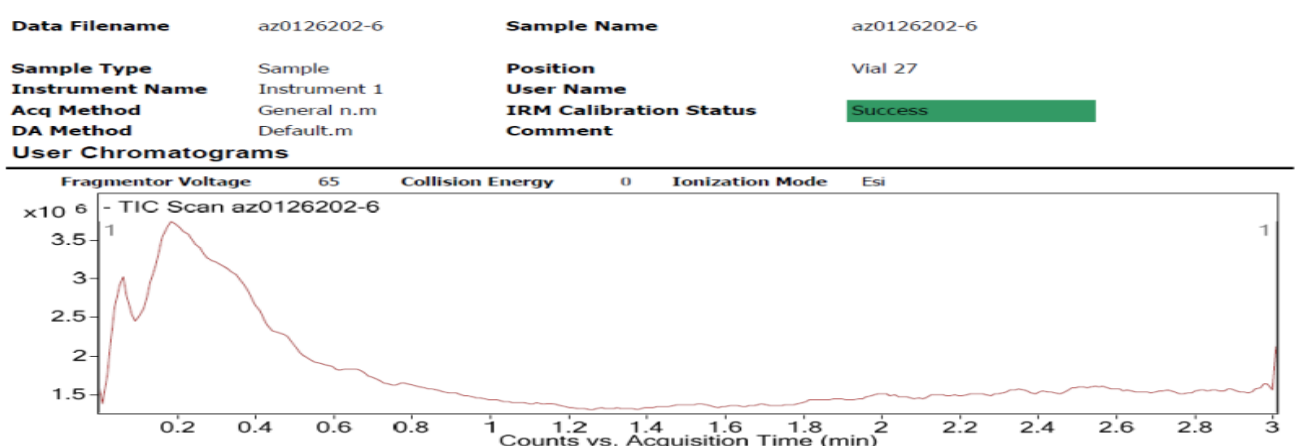

User Spectra

\begin{tabular}{cc} 
User Spectra & \\
\hline Fragmentor Voltage & Collision Energy \\
65 & Ionization Mode
\end{tabular}

$\times 104$ - Scan (0.195 min) az0126202-6

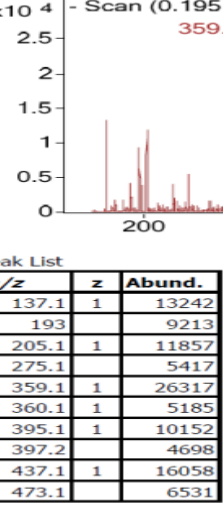

End Of Report -

Agilent Technologies

Page 1 of 1

Printed at: 11:27 AM on:1/27/2020

Figure 20. LC/MS chromatogram of isolated compound number 1

Molecular ion peak at $\mathrm{m} / \mathrm{z} 360$ that correspond to a molecular formula of C18H16O8(3,4Molecular ion peak at m/z359[M-H] of Rosmarinic dihydroxyphenyllactic acid) Rosmarinic acid and acid.

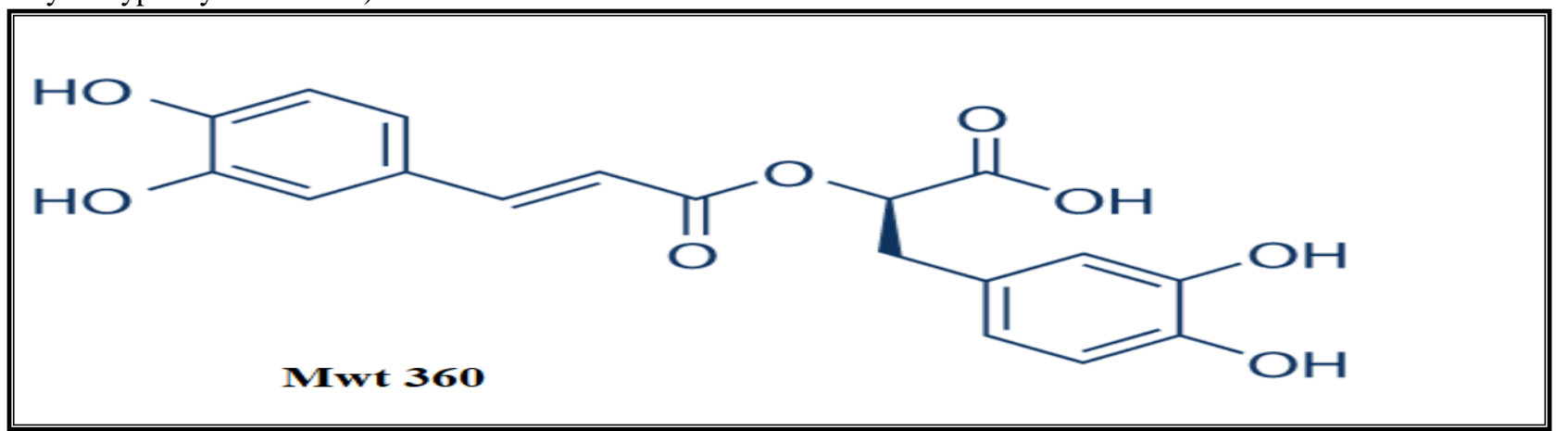

Figure 21. Chemical structure of Rosmarinic acid with molecular weight $360.31 \mathrm{Gram} / \mathrm{mol}{ }^{(18)}$ 


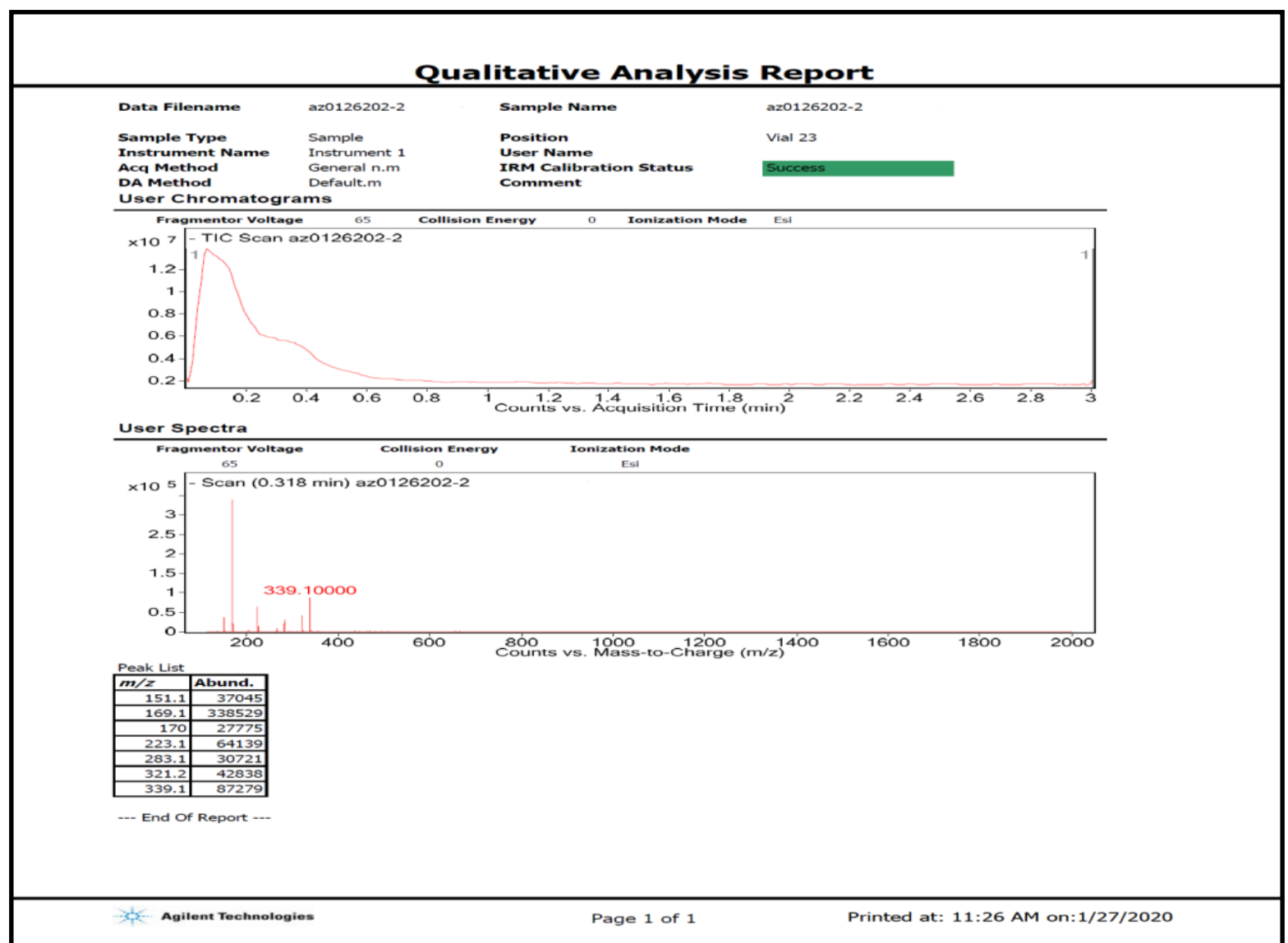

Figure 22. LC/MS chromatogram of isolated compound number 2.

Molecular ion peak at m/z 223 that correspond to the molecular formula of C11H12O5 (3,5-dimethoxy-4hydroxycinnamic acid) sinapic acid.

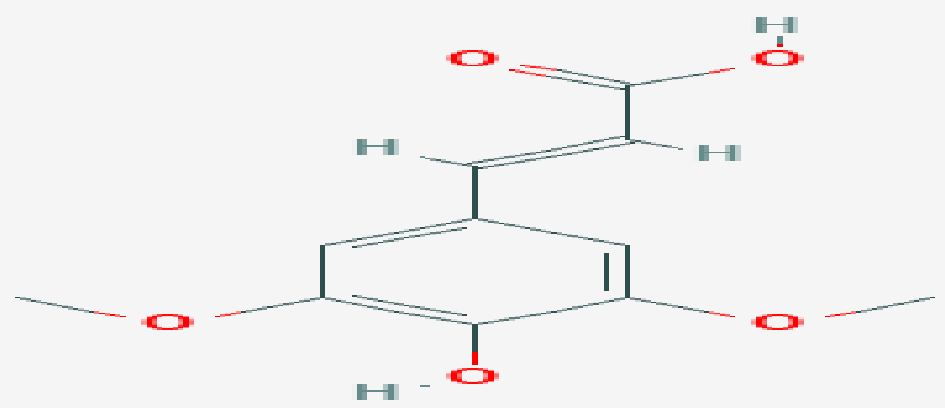

Figure 23. Chemical structure of Sinapic acid with molecular weight $224 \mathrm{Gram} / \mathrm{mol}^{(19)}$ 


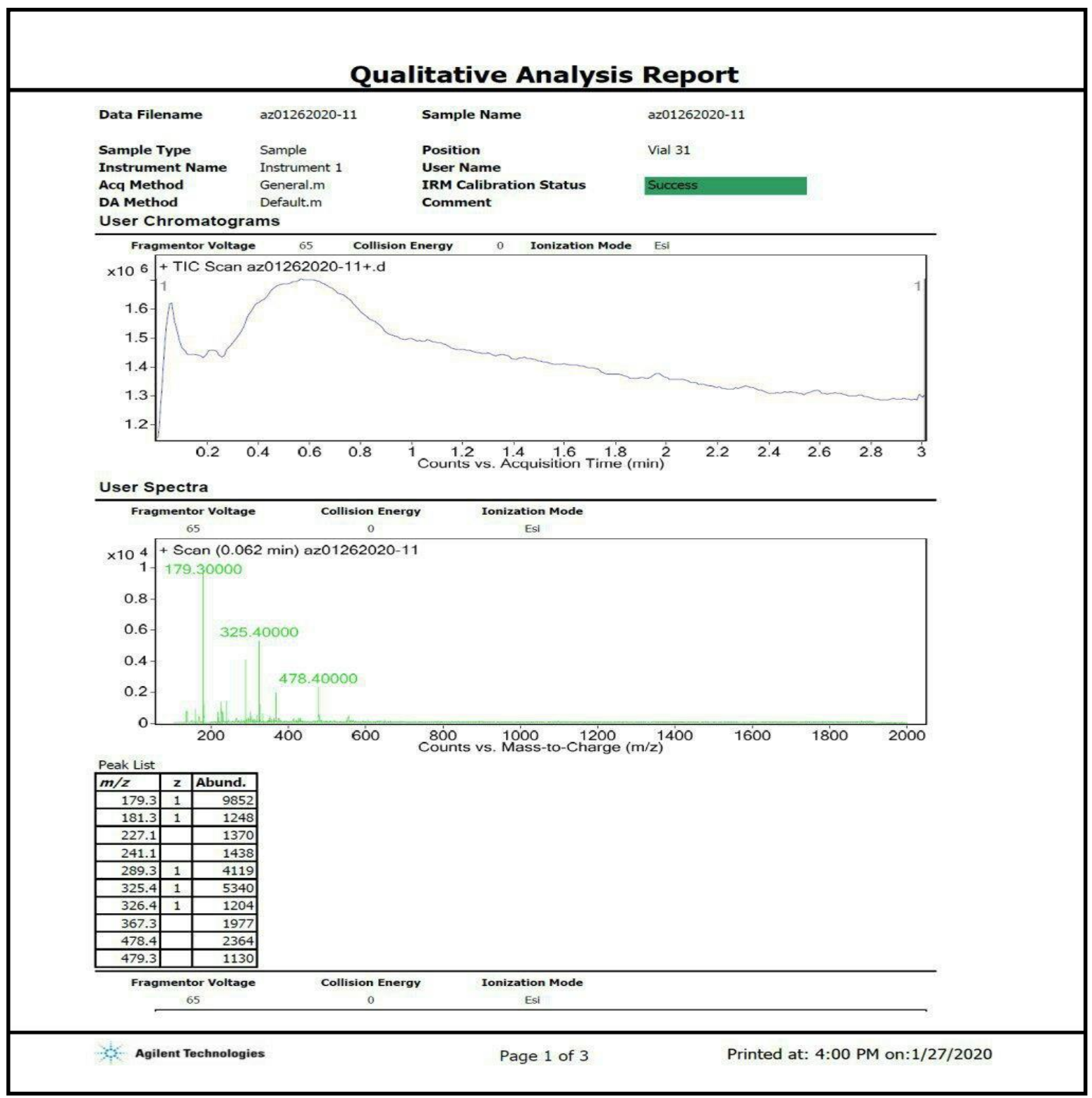

Figure 24. LC/MS chromatogram of isolated compound number 3.

Molecular ion peak at $\mathrm{m} / \mathrm{z} 181$ that correspond to the isotope of a molecular formula of $\mathrm{C} 9 \mathrm{H} 8 \mathrm{O} 4(3,4-$ dihydroxycinnamic) caffeic acid, and molecular ion peak m/z 179.3 [M-H]for caffeic acid.

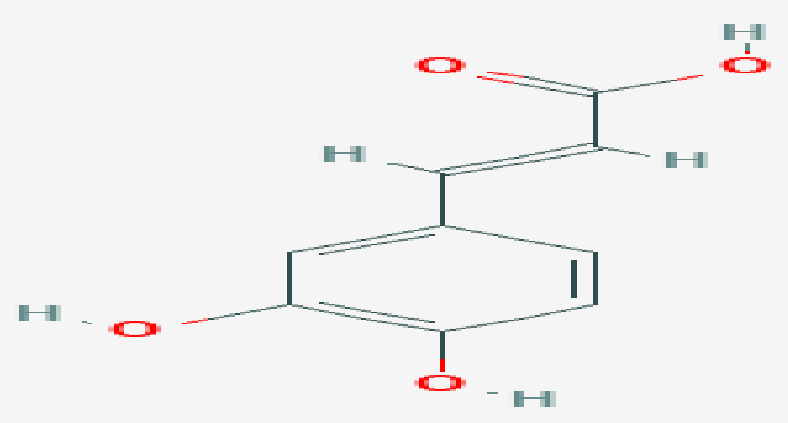

Figure 25. Chemical structure of Caffeic acid with molecular weight $180 \mathrm{Gram} / \mathrm{mol}^{(20)}$ 


\section{Conclusion}

In the light of the results obtained, the study concluded the following:

1. Phytochemical screening of new Iraqi plant Borago officinalis was done for aerial part of the plant nearly two hundred and fifty grams of the powdered plant material, and the results include the separation and identification of phenolic acids (Rosmarinic acid, caffeic acid and Sinapic acid).

2. Rosmarinic acid with Mwt 360 gram /mol isolated from ethyle acetate and n.butanol fraction with high quantity nearly 13.3 mg.

3. Sinapic acid with molecular weight 224 Gram/mol isolated from ethyle acetate fraction with small quantity nearly $6 \mathrm{mg}$.

4. Caffeic acid with molecular weight 180 Gram $/ \mathrm{mol}$ isolated from ethyle acetate fraction with high quantity nearly $9 \mathrm{mg}$.

5. All isolated phenolic acids were identified by TLC, preparative TLC, HPLC, UV, LC/Mass.

\section{Acknowledgements}

The authors are grateful to acknowledge the College of Pharmacy -University of Baghdad for providing the necessary facilities to carry out this study.

\section{References}

1. Ghahreman A. Flora of Iran. Tehran: Research Institute of Forests and Rangelands; 1978. Persian.

2. Pieretti PG, Palmegiano GB, Salamano G. Quality and fatty acid content of borage (Borago officinalis L.) during the growth cycle. Ital J Food Sci 2004; 16: 177-184.

3. Farhadi R, Balashahri MS, Tilebeni HG, Sadeghi M. Pharmacologyof Borage (Borago officinalis L.) medicinal plant. Int J AgronPlant Prod 2012; 3: 73-77.

4. Gudej J, Tomczyk M. Badania chromatograficzne związków polifenolowych w zielu Borago officinalis L.Herba Pol 1996; 42:252-6.

5. Basar SN, Rani S, Farah SA, Zaman R. Review on borage officinalis: a wonder herb. Int J Biol Pharm Res 2013; 4: 582-587.

6. Montaner C, Floris E, Alvarez JM.Geitonogamy :A mechanism responsible for high selfing rates in borage (Borago officinalis L.).Theor Appl Genet .2001;102 9(2):375 - 378

7. M. Asadi-Samani, M. Bahmani, M. RafieianKopaei, The chemical composition, botanical characteristic and biological activities of Borago officinalis: a review. Asian Pac. J. Trop. Med. 2014;7:22-28.
8. A. Ratz-Łyko, A. Herman, J. Arct, K. Pytkowska, Evaluation of antioxidant and antimicrobial activities of Oenothera biennis, Borago officinalis, and Nigella sativa seedcake extracts. Food Sci. Biotechnol.2014; 23(4): 1029-1036.

9. G. Oboh, A.O. Ademosun, Comparative studies on the ability of crude polyphenols from some Nigerian citrus peels to prevent lipid peroxidation in vitro. Asian J. Biochem. 2006; 1(2): 169-177.

10. M.D. Lozano-Baena, I. Tasset, A. MuñozSerrano, Á Alonso-Moraga, A. Haro-Bailón, Cancer prevention and health beneficesof traditionally consumed Borago officinalis plants. Nutrients 2016; 48: 8(1).

11. A. Crozier, E. Jensen, M.E.J. Lean, M.S. McDonald, Quantitative analysis of flavonoids by reversed-phase high-performance liquid chromatography. J. Chromatogr. A, 1997; 761: 315-321.

12. Gupta M, Singh S.Borago officinalis Linn. An important medicinal plant of Mediterranean region : Review .Int. J.Pharm Sci Rev Res .2010;5(1):27 - 34 .

13. Cetkovic GS, Dilas SM, Canadanovic-Brunet JM, Tumbas VT. thin-layer chromatography analysis and scavenging activity of marigold (calendula officinalis 1.) extracts. Apteff. 2003; 34:93-102.

14. Hamad MN. Detection and isolation of flavonoids from Calendula officinalis (F. Asteraceae) cultivated in Iraq. 2016; 25(2):1-6.

15. Wagner H., Bladt. plant Drug analysis:Thin layer Chromatography Atlas 2nd ed. Springervelag, Berlin, 1996:384.

16. Muhammed NA, Awad Z J .Phytochemical study of some medicinal compounds present in Cordia myxa L. plant cultivated in Iraq . A Thesis 2017 . p40.

17. Waksmundzka-Hajnos M, Sherma J, Kowalska $\mathrm{T}$, editors. Thin layer chromatography in phytochemistry. CRC Press; 2008:P 348.

18. Ying Zhang, Jonathan P. Smuts, Edra Dodbiba, Rekha Rangarajan, John C. Lang, and Daniel W. Armstrong . Degradation Study of Carnosic Acid, Carnosol, Rosmarinic Acid, and Rosemary Extract (Rosmarinus officinalis L.) Assessed Using HPLC. Journal of Agricultural and Food Chemistry 2012, 60 (36) , 9305-9314. 
19. J. Oszmian’ski ,Kolniak-Ostek J , Wojdyło A .Application of ultra performance liquid chromatographyphotodiode detectorquadrupole/time of flight-mass spectrometry (UPLC-PDA-Q/TOF-MS) method for the characterization of phenolic compounds of Lepidium sativum L. sprouts 2013: ;236,699706.
20. M. Nardini, M. D’Aquino, G. Tomassi, V. Gentili, M. Di Felice and C. Scaccini, Inhibition of human lowdensitylipoproteinoxidation by caffeic acid and other hydroxy- cinnamic acid derivatives, Free Radical Biol. Med. 1995: ;19,541. 